\title{
Die rol van die kerk as een van die instellings in die samelewing wat mense moreel vorm
}

\begin{abstract}
The church as one of the institutions in society plays an important role in the moral development of people

Throughout the ages, the church as one of the institutions in society has played an important role in the moral development of people; both in South Africa and abroad. However, since the recent political revolution in South Africa and the adoption of a new constitution, the state has been shifting into a neutral religious direction, so that no religion is favoured over another. This does not mean that churches have a less important role to play today. In fact, Christian churches still have a significant effect on communities. Therefore they have an even greater responsibility to convey Christian values and principles in order to educate their members in these matters in a dedicated way. For this purpose, the church needs a clear formulation of its moral message, as well as programmes by which to convey this message to its people.
\end{abstract}

1.

INLEIDING

Die artikel hanteer die belangrike saak van die rol van die kerk in die post-apartheid Suid-Afrika 'n vraagstuk wat om konstante besinning vra. Dit is'n diagnostiese artikel wat'n oorsig wil gee van die verskillende standpunte oor die rol van die kerk as een van die instellings in die samelewing wat die moraliteit van mense vorm. 'n Beoordeling van dié standpunte word aan die einde van die artikel gedoen aan die hand van Van der Ven se standpunt oor die rol van godsdiens en morele vorming.

In die artikel word die volgende bespreek: Enkele definisies van moraliteit, die kerk as morele gemeenskap en die verhouding tussen godsdiens en moraliteit.

2.

DEFINISIE VAN MORALITEIT

Talle publikasies oor morele vorming het die laaste om en by drie dekades uit die pen van Protestantse teoloë verskyn. Van die belangrikste werke in dié verband is dié van die sogenaamde postliberale teoloë in Noord-Amerika, denkers soos veral Stanley Hauerwas. Hierdie denkers staan krities teenoor die sogenaamde moderne benadering tot moraliteit. Volgens hierdie benadering word moraliteit verskraal tot die neem van morele besluite op rasionele gronde. Op hulle beurt staan hulle weer onder die invloed van filosowe soos Wittgenstein,Maclntyre en Taylor wat eweneens die modernistiese idee van 'n tradisie-onafhanklike, outonome etiek verwerp.

Binne die raamwerk van 'n postliberale, tradisie-afhanklike moraliteit word die deur geopen vir die beklemtoning van die morele agent (spesifiek die vorming van daardie agent) tot ' $n$ deugsame mens binne die geloofgemeenskap aan die hand van die narratiewe van daardie 
gemeenskap. Roebben (1997:436) is van mening dat moraliteit moet bydra tot sosiale kohesie: "De jeugd verkeert in moreel verval en dat is hoofdzakelijk te wijten aan de commercialisering van hun ontspanning, een gebrek aan ouderlijke interesse en autoriteit, en het fallen van morele en religieuze opvoeding".

Kretzschmar (2004:86) handhaaf die opinie dat moraliteit as "obedience to the unenforceable" gedefinieer word. "If morality and moral formation must not be confused with legalism, neither must they be confused with moralism. Moralism is pure human effort to be moral, often an anxious attempt at self-improvement. It is neither motivated nor assisted by God's grace. Christian morality, on the other hand, is good character and right action that develop out of faith and love for God." Die woord moraliteit het sy oorsprong in die Griekse woord ethos. Die Griekse woord ethos dui oorspronklik op die skuiling of woonplek van'n dier. Van dié woord word afgelei dat moraliteit gedrag volgens gewoonte is. Die begrip: moraliteit doen dieselfde vir die samelewing as wat die woonplek vir diere doen - dit gee sekuriteit, beskerming, standvastigheid en onderhoud. Moraliteit word dus die "gom" van die samelewing (Birch \& Rasmussen 1989:38). Die Latynse werkwoordsvorm van ethos beteken "om te meet". Die bedoeling is dat sake van morele aard geweeg en gemeet moet word. Daar moet 'n onderskeid getref word tussen wat reg of verkeerd, goed of sleg is. Vir Birch en Rasmussen en andere is die onderskeiding tussen moreel en immoreel dieselfde as die onderskeiding tussen wat moreel goed of moreel verkeerd of sleg is.

Die Nederlandse geleerde J Douma definieer die begrip moraliteit as die gebruike van die gemeenskap waar die onderskeid tussen reg en verkeerd van toepassing is. Filosowe soos Sokrates, Plato en Aristoteles het oor die eeue heen vrae gestel oor moraliteit. Dié vrae dui aan of dit reg of verkeerd, goed of sleg is. Die basiese vrae wat gevra word, is onder andere: "Wat is die sin van ons lewe, en hoe behoort ons te lewe? Wat moet ek met my lewe maak? Watter soort mense moet ons wees?"

AW Musschenga (1988) onderskei tussen breëre en engere moraliteit. Met "breëre moraliteit" bedoel hy daardie kwessies wat ook deel uitmaak van die etiese vrae, nl wat'n goeie samelewing en goeie mense behels. Met "engere moraliteit" bedoel hy die voorskrifte of reëls vir gedrag wat die mense in 'n gemeenskap in staat stel om in harmonie en vrede te leef. Moraliteit slaan dus op die sedelike gedrag van'n persoon volgens die waardes, norme en gewoontes.

Mense se lewenskwaliteit moet bevorder word om sodoende'n stabiele samelewing te skep. In die soeke na die herstel van morele waardes in ons land, kan daar so maklik in moralisme verval word. Met moralisme word bedoel die oproep tot mense om goeie morele waardes na te streef om sodoende van die samelewing 'n beter en veiliger plek vir almal te maak.

Die filosoof Immanuel Kant verstaan moraliteit "als iets waartoe wij ons verplicht weten, ondanks alle neigingen die ons tot handelen aanzette. Karakteristiek voor moreel handelen is dat het handelen is uit plichtsbesef" (Leijen 1992:90).

Moraliteit ontspring uit geloofsgemeenskap, maw word bepaal deur jou verhouding met God. Baie toegewyde mense sonder moraliteit, dikwels veral teenoor groepe wat van hulle verskil. Die mense wat bv apartheid ondersteun het, het ook sg "verhoudings met God gehad" - en tog het hulle' $n$ totaal immorele politieke stelsel ondersteun. Moraliteit bestaan as deel van die gemeenskap se toewyding aan God. Vroeëre filosofieë het ingesluit die begeleiding van siele of die siel se morele vorming.

Birch en Rasmussen gee 'n spesifieke siening oor Christelike filosofie: "The commonality of moral practice schools and the Christian communities is often striking. Thus Galen, a nonChristian writer of the second century, speaks about 'the Christian philosophy' as one which has also led people to lives of self-discipline and strict control in matters of food and drink and sexual conduct; to pursuit of justice; and to a 'contempt' for death, i.e., a lack of fear of death. 
And Justin Martyr, writing earlier in the same century, presents his conversion to Christianity as a conversion to this particular 'philosophy', albeit one in competition with the bioi (ways or styles of life) of other schools" (1989:24).

Volgens hierdie skrywers was vroeëre Christene se bekering 'n bekering tot ' $n$ spesifieke gemeenskapsmoraliteit wat deur gepaardgaande geloofstelsels, lering en instruksies ondersteun is, asook jou afgerig het vir'n spesifieke "way of life" (Birch \& Rasmussen 1989:22-23).

Abraham Kuitert konstateer dat die moraal van Europa veronderstel is om Christelik te wees. Hy meen egter dat die Christendom nie die uitvinder van moraliteit was nie, maar slegs die beskermer daarvan. Moraliteit, sê hy, is so oud soos die mensdom self. Dit is die belangrike faktor as dit kom by die mens se sosialiseringsprosesse (1999:284).

Verder meen Kuitert dat die mensdom moraliteit per definisie op 'n teenstrydige manier toepas (1999:284). Hy gebruik seksualiteit as'n voorbeeld. Hy gaan van die algemene stelling uit dat alle mense' $n$ behoefte aan ' $n$ maat het. Moraliteit word nou gebruik om die samelewing so gemaklik moontlik te maak. Aanwysings vir morele handelings kom nie van bo nie; dit is ook nie geopenbaar soos wat sommige Christelike gemeenskappe dit te kenne wil gee nie (1999:285). Moraliteit bevorder die sosialiseringsproses deur die mens as objek te gebruik (Kuitert 1999:285). 'n basis van'n morele beraad is aan die een kant die gemeenskaplike interpretasie van die tradisie. Aan die ander kant is dit dat elke mens in alle vryheid sy eie interpretasie sal doen. Albei interpretasies moet dan met mekaar geïntegreer word.

Kuitert is ook van mening dat' $n$ morele beraad nie met niks begin nie, of, soos hy dit stel, "begint niet bij nul" (1999:289). Moraliteit is volgens hom altyd gelyk aan die ander. Die verantwoordelikheid berus by die individu.

Kant verstaan moraliteit "als iets waartoe wij ons verplicht weten, ondanks alle neigingen die ons tot handelen aanzette. Karakteristiek voor moreel handelen is dat het handelen is uit plichtsbesef" (Leijen 1992:90). Sonder die morele tradisie, kan geen moraliteit bestaan nie, want moraliteit gaan oor die oorlewering en die instruksie van "die goeie mens" (Kuitert 1999:290). Hy gebruik die morele opvoeding, ens. Die bestaande morele tradisie vorm dus volgens hom die beginpunt van'n morele beraad.

Kuitert is verder van mening dat die publieke moraliteit gedra moet word deur die deelnemers wat in die vryheid hulle bydrae lewer (1999:290). Die deelnemers vorm die basis van die moraliteit. Sonder outonome draers, kan die morele beraad nie begin nie (Kuitert 1999:290).

Louise Kretzschmar gee die volgende definisie van morele vorming: "Moral formation can be defined as a process of character that issues in right and good conduct. Moral formation involves both 'being' and 'doing' (see Kretzschmar 2000); it is the development of righteous character through the exercise of virtues such as integrity, goodness, fairness and caring. This leads to the formation of the bedrock of moral identity which can issue in moral conduct such as just and compassionate action" (2004:86).

Lewis Mudge is van oordeel dat daar'n paar belangrike, maar ook moeilike, ondernemings is wat die morele samelewing langsaam dra. Die kerk en ander geloofsgemeenskappe het 'n belangrike rol hierin te speel, alhoewel dit 'n breë samelewingsverantwoordelikheid is. Wanneer daar oor die kerk as morele gemeenskap gepraat word, vind Mudge sy posisie in 'n sakramentele verstaan van die kerk. Dit sluit die ekklesiologiese en morele realiteit in. Só kom hy tot die opvatting dat die kerk as oikos en polis in albei die Bybel en kontemporêre wêreld optree. Morele vorming binne die kerk bring gemeenskappe voort in voeling met die wêreld met al sy probleme, daagliks geskaaf deur die vertelling van die Christusverhaal. Sulke morele vorming, sê Mudge, maak 
dissipels van geslag tot geslag. Daarom behoort die kerk homself te herontdek as die basis vir morele vorming.

Die rol van geskrifte in die gemeenskap, asook die besondere bewussyn dat hulle ' $n$ volk is, was kenmerkend van sowel die Judaïsme as die Christendom. "Peoplehood" verwys nie na enkelgemeenskappe nie, maar na pluralisme en konfederasie. Die Jode glo aan die gemeenskaplike omsluiting van geloof in een God. Vroeëre Romeine sien die Christelike "Mense van die Weg" as'n variant van die Joodse gemeenskaplikheid.

Downs meen "morality is, to a large extent, a matter of values. What a person values will shape the moral decisions he/she makes. So the church has been concerned with teaching people to value what God values and to hate what God hates. Unfortunately the approach normally used by the church of naming and communicating Christian values has not always been successful ... The values and moral perspective so carefully taught at home and at church were abandoned with relative ease when challenged by a secular society" (1997:96).

Smit beweer dat daar oor die algemeen duidelikheid is oor wat die "kerk" is of veronderstel is om te wees (1996b:120-121). Dit is redelik duidelik hoe "samelewings" en "samelewingsverbande" funksioneer of behoort te funksioneer en watter verbande saam 'n goeie samelewing behoort uit te maak. Dit is redelik duidelik wat dié soort kerk se unieke, dit wil sê eiesoortige, spesifieke, rol in dié soort samelewing behoort te wees (1996b:120).

Smit sê dat daar inderwaarheid nie iets soos "kerk" bestaan nie (1996b:120). Enige akademiese handboek of leerstuk van die kerk, maak dit met die eerste oogopslag baie goed duidelik. Reeds in die Nuwe Testamentiese tye en geskrifte kry 'n mens nie ' $n$ enkelvoudige voorstelling van wat die kerk is of behoort te wees nie (Smit 1996b:120). Die kerk, volgens Smit (1996b:120), het deur die loop van eeue ' $n$ versamelterm vir ' $n$ oneindige verskeidenheid bewegings, institusionele en organisatoriese vorme, groepe en gemeenskappe geword. Die talle bekende pogings om iets van hierdie veelvoud te behou deur dit tot basiese trajekte of modelle te sistematiseer (sien Dulles 1989), sowel as die talle invloedryke pogings om keuses te maak en sekere manifestasies van die kerk met behulp van fundamentele eienskappe, kenmerke of merktekens as normatief te probeer verdedig, illustreer eintlik maar net die ingewikkeldheid en omstredenheid van dié onderneming verder.

Smit verwys na ses gestaltes van die kerk. Die eerste is die kerk as aanbiddende gemeenskap (byvoorbeeld in die sin van "Ons gaan Sondae kerk toe"). Die tweede is die kerk as plaaslike gemeente (byvoorbeeld in die sin van "Is julle aktiewe lidmate van die kerk?"). Derdens is die kerk as denominasie (byvoorbeeld in die sin van "Aan watter kerk behoort julle?"). Vierdens verwys hy na die kerk as (streeks- of nasionale) ekumeniese liggaam (byvoorbeeld in die sin van "Wat sê die kerk oor die werkloosheid in ons land?"). Dan volg die kerk as vrywillige organisasie, beweging, inisiatiefgroep, vereniging of diensgroep (byvoorbeeld in die sin van "Is die kerk aktief betrokke by die bewaring van die omgewing?"). Laastens noem hy die kerk as die individuele gelowiges (byvoorbeeld in die sin van "Die kerk is geroep om die lig van die wêreld te wees") (Smit 1996b:120). [Sien ook sy artikel (1996a) getiteld "Reformed Ethics and Economic Justice" in die Nederduitse Gereformeerde Tydskrif (NGTT) waarin hy ook die ses gestaltes beskryf. Al hierdie gestaltes het goeie potensiaal vir morele regenerasie. Sien verder Dulles se Models of the Church. A critical assessment of the Church in all its aspects ( $2^{\text {nd }}$ edition) waarin hy die volgende gestaltes van die kerk onderskei: die kerk as instituut, as mistieke gemeenskap, as boodskapper en as dienskneg (1987: 34-89).

Bruce J. Nicholls (red.) (1986) onderskei die volgende gestaltes van die kerk. Die kerk (met spesifieke verwysing na die plaaslike gemeente) is die gemeente as lewende organisasie; die gemeente as georganiseerde gemeenskap; die gemeente as aanbiddende gemeenskap; die gemeente as delende gemeenskap en die gemeente as getuigende gemeenskap. Bush (1986:90) 
is van mening dat die plaaslike gemeente die ruimte is waar God sy verlossingsplan aan die wêreld bekend maak.

Küng gaan van die voorveronderstelling uit dat die kerk ook as'n "gemeenskap" beskou word (1973:84). Chapman is van mening "Community is one of those buzz-words which is used by religious and political thinkers throughout the world; it is often seen as the panacea for all the problems facing contemporary societies. If only we can give people face-to-face communities where everybody knows everybody else and where the communal values of family and tradition are upheld, so the argument goes, then all the problems of crime, lack of participation in politics, juvenile delinquency, teenage pregnancy, and other social disorder, will be almost solved" (2004:1).

Küng toon egter aan dat deur gemeenskap te benadruk, word die kerk (ekklesia) nie beskou as 'n abstrakte en verafgeleë superorganisasie met verskillende funksies wat bó die konkrete vergaderde gemeenskap geplaas is nie. Die kerk moet eerder gesien word as ' $n$ gemeenskap van mense wat gereeld ontmoet op 'n gegewe plek en tyd met 'n gegewe doel (1973:84). Hy is van mening dat die kerk ook nie gesien moet word as 'n gediskonnekteerde, geïsoleerde en onafhanklike godsdienstige groep nie. Dit moet gesien word as ' $n$ plek waar "the members, united through their individual service, of an all embracing fellowship" (1973:85) byeenkom.

Küng sê die term "kerk" word ook gewoonlik in verband gebring met die universele kerk (1973:85). Hy noem dat die plaaslike gemeente nie net tot die kerk behoort nie - die plaaslike gemeente is die kerk. Küng oordeel "the local church is not a small cell of the whole, which does not represent the whole and which has no purpose in itself. It is the real Church, to which in its own local situation everything is given and promised which it needs for the salvation of man in its own situation, the preaching of the Gospel, baptism, the Lord's Supper, different charisms and 89 ministries" (1973:85). Die kerk kan nie opgebreek of beperk word nie. Dit is die ekklesia van God en bestaan op alle plekke. Elke ekklesia, elke gemeente, die gemeenskap, is die Kerk van God (Küng 1973:83).

Omdat die kerk as'n instituut binne die Suid-Afrikaanse samelewing nog steeds'n beduidende invloed daarop uitoefen, is dit noodsaaklik dat die kerk die effektiwiteit van sy programme sal hersien, aangesien dit skynbaar nie die huidige morele verval kon verhoed nie. Die feit dat die staat tans geen godsdiens bevoordeel nie, plaas'n groter verantwoordelikheid op die kerk om sy boodskap en beginsels in die samelewing te laat geld en veral sy eie lidmate goed te onderrig in die waardes en norme wat hy voorstaan.

Om die rol van die kerk ten opsigte van morele vorming beter te belig, word verwys na die standpunte van internasionaal-erkende teoloë, byvoorbeeld Westerhoff, Merton Strommen (1979), Roebben, asook Suid-Afrikaanse teoloë soos Pityana en Villa-Vicencio, Burger (2000) en Jones.

Westerhoff reken dat die kerk vandag deur middel van effektiewe morele vorming die "gebroke ekologie" sinvol kan hervorm (1976:13). Met "gebroke ekologie" verwys hy na'n situasie waarin die tradisioneel behoudende gesin, skool, kerk en die breër samelewing permanent verander is deur' $n$ pluraliteit van godsdienstige en sekulêre oortuigings. Rasmussen wys daarop dat die kerk, saam met die gesin, skool en woonbuurt as sogenaamde "communities of intimacy", 'n belangrike rol te speel het in morele vorming (1993:14). Rasmussen (1993:14) meen dat die benaming "kerk" dikwels beskou word as die deurslaggewende leidraad tot die ontbrekende wese en vorm van die samelewing. "Kerk" gee 'n naam aan die betrokke gemeenskap en onderskei dit van ander gemeenskappe (1993:14).

Aan die hand van twee voorbeelde verduidelik hy hoe dubbelsinnig die Christelike lewe kan wees: Die Afrikaner wat, ten spyte van 'n eerlik-geskoeide gewete wat met sorg en ywer deur moreel-toegewyde geslagte in 'n moreel-kragtige kerk gevorm is, apartheid verdedig. Vergelyk 
ook die Amerikaanse televisiereeks The Civil War, en die prys wat hulle bereid was om te betaal vir hulle Christelike oortuigings (1993:14).

Pityana en Villa-Vicencio gaan van die voorveronderstelling uit dat ná die einde van die era van apartheid daar'n nuwe uitdaging vir die kerk is om sy geloof in die lig van die maatskaplike, politiese en kulturele veranderinge en gepaardgaande strukturele armoede te herdefinieer. Dit is dus duidelik dat daar 'n sterk behoefte bestaan aan morele vorming.

Roebben sien morele opvoeding as'n seismografiese funksie (1997: 436). Hy bedoel daarmee dat die jeug afstand doen van hulle waardes. Daar is dus'n skerper demonstrasie van'n beweging wat reeds in die samelewing aan die gang is. Roebben (1997:436) sê verder: "De stand van zaken in de hedendaagse theorievorming van de morele opvoeding is bij uitstek een seismograaf van de bewegingen in de sameleving: de moraalpedagogiek registreert de stilzwijgende veranderingen door methode ontwikkeling, zij vangt de schokgolven op door radicale standpuntbepalingen voor het welzijn van het kind en wordt ter verantwoording geroepen wanneer de samenleving uit haar legitimerend verhaal".

Mead gee 'n beskrywing van die paradigmaverskuiwing wat die kerk te wagte kan wees (1991:45). Hy meen dat die samelewingskonteks waarin die kerk hom tans bevind, grootliks verskil van dié van die vorige era. Dit beteken dat die kerk sy roeping en taak ten opsigte van die uitdagings van sy tyd moet herdefinieer. In sy eie woorde: "In this society one has fewer and fewer opportunities to find community; congregations in the past have been important sources of community, and a major challenge to congregations everywhere is to feed the world's need for community of meaning and relationship"

Mead stel die volgende vraag: "Where is the community I knew as a child? What a tiresome refrain that has become. My nostalgia blots out things I'd rather not remember - such as living on the 'right' or 'wrong' side of the tracks, the systemic devaluation of women and girls, the inability to cope with ethnic diversity, the economy that favored me at the expense of many others, the racial phobias we breathed" (1991:45).

Volgens Mead het daar in die kerkgeskiedenis drie paradigmaverskuiwings plaasgevind (1991:45). Die eerste twee paradigmaverskuiwings verwys na die apostoliese paradigma (wat gegaan het oor die getuienistaak van die kerk) en die Christendom-paradigma (wat verwys na die uitbreiding na ander lande om die sendingtaak voort te sit). Die derde paradigma is nog in wording.

Mead sê die vernaamste uitdagings van die kerk lê op die volgende terreine:

- die toerusting en opleiding van die amp van gelowiges;

- die herdefiniëring van die amp en rol van die predikant;

- die taak van teologiese beoefening; en

- die kerk se funksionering in sy administratiewe gestalte (1991:47).

Burger, 'n praktiese teoloog, bespreek die rol van die kerk in morele vorming aan die hand van vier belangrike vrae (2000:229):

\subsection{Staan moraliteit sentraal genoeg in die Christelike geloof dat 'n mens só 'n bydrae van die kerk kan verwag?}

Burger glo dat daar baie mense is wat nie werklik verwag dat die kerk'n oplossing kan bied vir die morele krisis in die land nie. Volgens hom is die vraag eintlik of lede van die kerk die wil het om hulle lewe volgens ander waardes as dié van die wêreld in te rig. Hyself is daarvan oortuig dat die kerk ' $n$ toonaangewende rol te speel het in die ontwikkeling van morele identiteit in die samelewing. Die kerk kan dus kan help met die oplossing van die morele krisis in Suid-Afrika.

Dit is vir Burger duidelik dat die kerk as geloofsgemeenskap, en in 'n mindere mate ook die skool by uitstek die omgewing is waar mense morele waardes kan internaliseer. Hy maan egter 
dat ons altyd moet onthou dat die kerk slegs'n instrument in die hand van die Heilige Gees is. Dit is slegs deur die werking van die Heilige Gees dat die mens die grondige hartsverandering en vernuwing van gedagtes kan beleef wat nodig is om 'n Geesvervulde lewe te voer en 'n moreelgoeie mens te wees. Die kerk bestaan dus nie in isolasie nie, maar moet goeie morele waardes in die wêreld uitleef en 'n verskil maak aan die nood van die wêreld.

Volgens Burger is dit belangrik dat 'n gemeente as geloofsgemeenskap met die oog op die skep van ' $n$ beter samelewing meer aandag moet skenk aan die morele sy van die evangelie (2000:230-240). In die verlede, en selfs nou nog, gaan dit vir die gemeente eerder oor die regte geloof as oor die regte lewe. Mense dink dat die belydenis van ' $n$ regte geloof outomaties lei tot die regte werke, terwyl 'n regte lewe en regte werke daagliks 'n doelbewuste keuse is. Dit gaan oor die keuse wat Christus sou gemaak het in bepaalde situasies en omstandighede. Christus se volgelinge moet immers in alles strewe om meer en meer soos Hy te wees.

In die verlede het bedieningspatrone, soos byvoorbeeld die sending, in so 'n mate beslag op gemeentes gelê dat ander aspekte soos die begeleiding van lidmate om 'n moreel-goeie lewe na buite uit te leef, afgeskeep is. Dit het tot gevolg gehad dat die wêreld daarbuite die kerk begin kritiseer het as 'n groep skynheilige en apatiese mense wat met hulle monde bely dat hulle Christene is, maar wie se lewe nie daarvan getuig nie. Burger sê dat die kerk sodanig geloofwaardigheid verloor het en dat baie mense hulle nie meer aan die kerk se boodskap steur nie, omdat hulle nie ervaar dat kerkmense regtig anders is nie (2000: 232).

\subsection{Hoe lyk 'n Christelike lewenstyl?}

Hier gaan dit vir Burger oor die inhoud van die Christelike lewenstyl en die vraag na die uniekheid van die Christelike moraal in vergelyking met die algemene moraal wat ons as Christene met ander groepe deel.

As Christene glo ons dat ons moreel so moet leef dat die vrug van die Gees in ons lewe sigbaar kan wees. Ook verwag God van ons om in gehoorsaamheid heilig (moreel goed) te leef in ons strewe om gelykvormig aan Jesus Christus te wees. As Christene glo ons egter dat ook ongelowiges moreel goed kan leef omdat God die Skepper en Vader van alle mense is en sy wet in die hart van mense geskryf is.

\subsection{Wat is die kerk se rol ten opsigte van morele vorming?}

Volgens Burger het die kerk in die verlede baie moeite gedoen om mense te help om die geloofsinhoud reg te verstaan, terwyl min aandag aan die uitlewing van dié geloof gegee is. Daar is ook min aandag gegee aan die kerk se rol ten opsigte van morele vorming.

Met verwysing na Hauerwas se teorie oor morele vorming, sê Burger dat karakter nie in die eerste plek deur die rasionele oordrag van kennis gevorm word nie, maar deur sosialisering en modellering binne 'n gemeenskap aangeleer word (2000:237). In die konteks van die geloofsgemeenskap speel leiersfigure na wie as "modelle" of "helde" opgesien word 'n belangrike rol. Sulke gemeenskappe vind gewoonlik hulle identiteit, visie en energie in verhale wat oor die gemeenskap vertel word. Hierdie verhale speel 'n sentrale rol in die vorming en vestiging van waardes en deugde by die jongmense van die geloofsgroep.

Volgens Burger word deugde en deugsaamheid ook gedeeltelik deur deelname aan die eiendomlike (liturgiese) praktyke van die kerk gevorm. Dit is egter duidelik dat indien kennis nie met die nodige hartsverandering gepaard gaan nie, morele identiteitsvorming nie sal plaasvind nie en waardes nie sal internaliseer nie. Om hierdie rede is Burger se beliggamingsteorie baie belangrik (2000:239).

In die eerste plek wil hy in ooreenstemming met die reformasie ook binne die praktiese teologie daaraan erkenning gee dat geloofs- en morele vorming uiteindelik die werk van die Gees is. 
Tweedens gaan hy van die veronderstelling uit dat die Gees sy vormingswerk doen terwyl ons in gehoorsaamheid aan God onsself oopstel vir bepaalde geloofspraktyke.

\subsection{Hoe vervul gemeentes en gelowiges die openbare funksie van die kerk?}

Burger is van mening dat gemeentes en individuele gelowiges op ten minste vier vlakke' $n$ bydrae kan lewer (2000:241).

Die heel belangrikste is waarskynlik gereelde voorbidding vir die staat, owerhede en die openbare lewe. Dit is belangrik dat kerke hulle nie terugtrek in ' $n$ ghetto-bestaan eenkant van die gemeenskap nie. Gemeentes en lidmate moet aangemoedig word om op konstruktiewe vlak betrokke te raak by hulle plaaslike gemeenskappe. Die kerk in die breë, asook plaaslike gemeentes en gelowiges, het die taak om aan die openbare gesprek deel te neem en te help met meningsvorming. Christene moet saampraat oor openbare kwessies en probleme en hulle perspektief daaroor deel maak van die gesprek. Christene het veral 'n plig om saam met die res van die samelewing erns te maak met die groot en knellende probleme wat die lewe van die samelewing bedreig. Die probleme en pyn van die land is ook ons pyn. Gemeentes en lidmate moet aangemoedig word om as Christene by openbare gemeenskapsaksies betrokke te raak en hulle gewig daar in te gooi.

Smit is van mening dat met betrekking tot ekonomiese geregtigheid, ons ook genoop word om te vra: "Beoefen ons ekonomiese geregtigheid? Beoefen ons kerk ekonomiese geregtigheid? Dra Suid-Afrikaanse kerke en gelowiges by tot die implementering van die Heropbou- en Ontwikkelingsprogram (HOP), of ondersteun ons net die visie en verwag implementering van ander (1996a:443)?

Smit sê verder dat in die Belydenis van Belhar, die Verenigende Gereformeerde Kerk van Suider-Afrika erken het dat ons visie van God en sy geregtigheid ernstige implikasies vir onsself, vir ons eie lewe as kerk en as gelowiges het (1996a:443-444).

Maar hoe raak die kerk betrokke in die bevordering van ekonomiese geregtigheid? Smit sê dat dit nodig is om versigtig onderskeid te maak wanneer ons die uitdrukking "kerk" in dié verband gebruik (1996a:444). "Kerk" het'n verskillende betekenis vir verskillende mense en groepe.

In sy baie waardevolle studie oor die kerk, argumenteer Wolfgang Hüber dat verskeie mense verskillende assosiasies maak wanneer hulle die woord "kerk" hoor. Sommige dink aan die fisieke gebou waar aanbidding plaasvind, sommige dink aan ampsdraers soos die priesters self. Ander dink aan die lidmate, sommige dink aan aanbiddingsdienste, sommige dink aan streeksen nasionale kerklike liggame, en nog ander dink aan ekumeniese liggame (sien die verwysing by Smit 1996a:444).

In 'n artikel "After ten years, public theology in post-apartheid South-Africa", spreek Koopman die mening uit dat die Suid-Afrikaanse sogenaamde "struggle"- en "status quo"-kerke kan voordeel trek uit Hauerwas se nadenke oor hoe en op watter maniere hulle betrokke kan raak in die samelewing. Hierdie kerke sal binne die samelewing betrokke moet raak, nie net om demokrasie te laat werk nie, maar om getrou te wees aan hulle roeping en aan die drie-enige God.

In die kerk se stryd om suksesvol by te dra tot die nuwe staat, moet die kerk waaksaam wees om nie in die strik van Konstantinisme te val nie. Dit is moontlik dat die vorige "status quo"-kerke gekoöpteer kan word om met die politieke en ekonomiese sisteem saam te werk as berouvolle gebaar vir hulle deelname aan apartheid. Hauerwas se teologie herinner die kerk egter aan sy unieke motivering en bydrae in die lig van die belangrike riglyne vir die rol van publieke teologie in die Suid-Afrikaanse kerke.

Jones (2005:8) by Burger (2000) aan wanneer hy sê dat ons in 'n wêreld lewe waar mense al hoe meer geneig is om self te kies tussen reg en verkeerd. Hierdie mense beskou hulleself as die 
enigste bron vir die bepaling van moraliteit. Hulle kies doodgewoon die waardes waarmee hulle gemaklik voel.

Moraliteit kan egter nooit net 'n persoonlike saak wees nie. Waar individue nie deel is van 'n breër historiese, sosiale en godsdienstige konteks nie, kan 'n afgestompte moraliteit maklik ontstaan wat selfliefde, eiesinnigheid en eiebelang aanmoedig en versterk. Jones sê verder dat individue wat op grond van wat vir hulle voordeel inhou self besluit oor moraliteit, 'n etiek van verantwoordelikheid erg in die wiele kan ry. Waar moraliteit net op die self gerig is, ontstaan gewoonlik'n stuk etiese egoïsme wat bitter min ruimte vir ander en vir God laat (2005:8).

4. GODSDIENS EN MORALITEIT

\subsection{Die verhouding tussen godsdiens en moraliteit}

Godsdiens het nie slegs ' $n$ invloed op sogenaamde private morele aangeleenthede nie. Daar is oorgenoeg bewyse dat godsdiens inderdaad mense se houding oor morele kwessies soos aborsie, selfmoord, genadedood, die huwelik, egskeiding en die gesinslewe asook hulle politieke en ekonomiese keuses, beïnvloed. Moraliteit is ' $n$ integrale (en vir die meeste mense inderwaarheid die vernaamste) bepalende subteks, en dien as kriterium om te bepaal of ' $n$ individu, sosiale groep of gemeenskap enigsins godsdienstig is (1998:13).

Moraliteit en godsdiens is dus integraal verwant en kan daarom nie geskei word nie. Godsdiensbronne moet binne hierdie raamwerk van intertekstualiteit ondersoek word om hulle morele waarde te bepaal. Van der Ven (1998:15) beskryf die verband tussen godsdiens en moraliteit op 'n immanente sowel as transenderende vlak.

\subsection{Die verhouding tussen godsdiens en moraliteit op immanente vlak}

Godsdiens speel'n drievoudige rol wat moraliteit op immanente vlak betref:

In die eerste plek integreer godsdiens eksterne idees, oortuigings, waardes en norme deur dit in verband te bring met die Christelike hooftemas soos skepping, vervreemding, vrymaking en eskatologiese voleinding (1998:16). Hierdie integrasie het tot gevolg dat verskillende morele kategorieë by mekaar aansluit, soos vryheid en verantwoordelikheid, geregtigheid en liefde en skaamte en skuld.

In die tweede plek rig godsdiens hierdie morele elemente in 'n nuwe rigting: hoop op die nuwe hemel en die nuwe aarde, die koninkryk van God, die nuwe Jerusalem (1998:16). Die ongebrokenheid van hierdie nuwe oriëntasie kan tot die herprioritisering van godsdienstige elemente lei, byvoorbeeld morele waardes bo rituele, liefde bo orde. Hierdie nuwe oriëntasie vuur sekerheid, vertroue en hoop aan (1998:16).

In die derde plek speel godsdiens op immanente vlak 'n kritiese rol tov moraliteit (1998:16). Ooreenkomstig die intrinsieke waarde van die natuur en die mensdom soos God dit met die skepping bedoel het, verskaf dit morele kritiek op historiese ontwikkelinge soos die moderne kapitalisme (1998:16).

\subsection{Die verhouding tussen godsdiens en moraliteit op transenderende vlak}

Godsdiens dra nie inhoudelik iets by tot nie-godsdienstige moraliteit nie. Moraliteit, kan egter deur die integrasie daarvan met godsdiens op transenderende vlak verryk word.

Die Christelike godsdiens verskaf op radikaal-morele vlak nie net 'n raamwerk vir idees, 'n lys deugde en 'n waardestelsel nie - die godsdienstige opvatting van moraliteit behels ook die omkering van die algemene morele sin, gewoontes en gebruike, selfs die Christelike deugde, waardes en norme. Godsdiens speel inderdaad 'n deurslaggewende rol in die openbare lewe. 
Ons is van oortuiging dat godsdiens dalk selfs ' $n$ groter substansiële bydrae tot die inhoud van moraliteit lewer as wat Van der Ven meen.

5. KONKLUSIE

Dit is vir ons duidelik dat die kerk, benewens appèlle uit verskeie instansies, ten diepste deur teologiese oorwegings gedryf word om by morele vorming betrokke te wees. Volgens die teoloë na wie ons hierbo verwys het, kan die kerk deur middel van effektiewe morele vorming die samelewing sinvol hervorm. Die uitgangspunt is dat die kerk'n meer praktyk-gerigte benadering moet hê om sodoende kritiese denke oor die beskikbare sosiale prosesse te stimuleer. Dit beteken ook dat die kerk sy roeping en taak ten opsigte van die uitdagings van sy tyd moet herdefinieer. In post-apartheid Suid-Afrika bestaan'n nuwe uitdaging vir die kerk om sy geloof in die lig van die maatskaplike, politiese en kulturele veranderinge en gepaardgaande strukturele armoede te herdefinieer. Die kerk kan 'n toonaangewende rol speel in die ontwikkeling van morele identiteit in die samelewing, en kan aldus help met die oplossing van die morele krisis in Suid-Afrika. Moraliteit kan egter nooit net'n persoonlike saak wees nie.

Die Westerse kerke staan meer as ooit tevore in die middel van die krisis. Daar is egter ook ander faktore wat tot dié krisis bydra. Die vernaamste hiervan is: die veelvuldige keuses wat die modernisme aanbied; ' $n$ sterk afname in kerklike en godsdienstige aktiwiteite; groter klem op die individu se persoonlike belange en voorkeure; die geloofwaardigheid van die kerk in 'n pluralistiese samelewing en 'n mentaliteitsverandering, veral onder die mense vanuit die Eerste Wêreld. Samelewingsveranderinge, die invloed van breër kultuurprosesse, die groeiende ervaring van pluraliteit, die blootstelling aan ander waardestelsels, ander kulturele erfenisse en ander godsdienste, dwing ons om opnuut oor ons eie waardes en wêreldbeskouing na te dink. Die modernisme, post-modernisme en globalisering word ook as bydraend tot die oorsake van die moraliteitskrisis beskou.

\section{BIBLIOGRAFIE}

Burger,CW 2000. Nie goedgelowig nie maar gelowig en goed: oor die uitdaging van beter morele vorming in gemeentes. Skrif en Kerk. Jaargang 21 (2) 2000; 230-242.

Birch, BC \& Rasmussen, LR. 1976. Bible and Ethics in Christian Life? Minneapolis: Augsburg.

Dulles, A. 1988. Models of the Church. A critical assessment of the Church in all aspects. Ireland: Gill and Macmillan.

Groome, TH. 1980. Christian Religious Education. San Francisco: Harper.

Groome, TH. 1991. Sharing faith. A comprehensive approach to religious Education \& Pastoral Ministry.The way of shared praxis. New York: Harper Collins.

Kretzschmar, L \& Hulley, L (eds) 1998. Questions about Life and Morality: Christian Ethics in South Africa today. Pretoria: JL van Schaik Religious Books.

Kuitert, HM. 1992. Het algemeen betwijfeld Christelijk geloof. Ten Have: Baarn.

Kuitert, HM. 1999. Kennismaken met Kuitert. Een overzicht van zijn Theologie. Ten Haven/Baarn.

Kung, H. 1992. Een coalitie van gelovigen en nie-gelovigen, In H. Kung: Mondiale verantwoordelikheid. Kok: Kampen, pp. 54-73.

Leijen, A. 1992. Profielen van Ethiek van Aristoteles tot Levinas. Dick Couthino: Muiderberg.

Mead, L. 1991. Five Challenges for the Once and Future Church. An Alban Institute Publication.

Mudge, LS. The Church as Moral community

Musschenga, AW.1988. De universele moraal als opdracht, in Gäbler K.U. et. al. (eds.): Geloof dat te denken geeft, $p .152-178$. Baarn:Ten Have.

Pityana, BN \& Villa-Vincensio,C (eds.). 1995. Being the Church in South Africa Today. Johannesburg: SACC. Rasmussen, L. 1993. Moral Fragments and Moral Community. New York: Orbis. 
Roebben, B. 1997(b) Moraalpedagogiek: Een bewogen discpline. Levense Perspectieven, 51(4), 436-462. Smit, DJ. 1996a. Reformed ethics and economic justice in: NGTT XXXVII, 3, p.439-455.

Smit, DJ.1996. Oor die kerk as'n unieke samelewingsverband. Tydskrif vir Geesteswetenskappe (2). 1996. Strommen, MP. 1979. Five Cries of Youth. San Francisco: Harper\& Row.

Wainwright, G. 1996. Four our Salvation. Grand Rapids, Eerdmans.

Wells, D.F. 1998. Losing our virtue - why the church must recover its moral vision. Grand Rapids: Eerdmans. Westerhoff, JH.1972a. A Socialization model, in Westerhoff, JH (ed). A Colloquy on Christian Education. New York: The Pilgrim Press.

Westerhoff, JH. 1975. Will our children have faith? New York:Seabury.

Villa-Vicencio, C \& De Grunchy, J. 1994. Doing Ethics in context. South Africa Perspectives. New York: Orbis.

\section{TREFWOORDE}

Moraliteit

Morele vorming

Geloofsgemeenskap

Kerk

Waardes

Godsdiens

\section{KEY WORDS}

Morality

Moral Formation

Faith-community

Church

Values

Religion

\section{KONTAKBESONDERHEDE}

Dr NC Philander

Fakulteit Teologie

Universiteit van Stellenbosch

Dorpstraat 171

Stellenbosch 7600

Tel: 0832706146

E-pos: vgk@sun.ac.za 